\title{
Introduction to Special Issue: Making a Hindu Saint
}

\author{
Dean Accardi
}

Published online: 26 November 2018

(C) Springer Nature B.V. 2018

There has long been academic interest in the saints of India's past whose legacies today are celebrated across religious and national landscapes. The legacies of Hindu saints accompany images revered at temples, are recited at festivals and political rallies, and are read by both devotees and casual readers in pamphlets, comic books, devotional books, and popular literature. However, when scholars research these legacies, they often find significant differences between saints' current legacies and those found in the earliest archival materials. At times, even major portions of current legacies are missing entirely in the early archive. Unable to be traced back to the saints themselves, many stories, writings, or other aspects of these saints' legacies appear to have only emerged much later from traditions seeking to memorialize them.

While some have dismissed these changes and additions to saints' life narratives as accretions that must be purged from saints" "true legacies," a number of recent scholars have taken interest in such hagiographical accounts, even if "altered and accrued," as valuable in their own right. Felice Lifshitz spoke of this scholarly transition towards reconsidering the value of late hagiographies in the European context as a

move from searching for the original version of each particular saint's biography to studying all extant versions, each in its particular compositional context. Instead of seeing "legendary accretions" as dross to be sifted and cleared away, scholars have seen transformations in a saint's character as crucial indicators of many different sorts of changes over time (1994: 95).

Dean Accardi

daccardi@conncoll.edu

Department of History, Connecticut College, New London, CT 06320, USA 
This scholarly transition towards valuing and attending to later additions to a saint's hagiography and oeuvre has been underway in scholarship on Hindu saints for some time as well. For example, throughout his extensive scholarship on bhakti saints, John Stratton Hawley (1988) has identified many instances in which narratives of saints or poems attributed to them are unable to be traced to the saints themselves. Instead of dismissing them, Hawley analyzes how and why poems and hagiographical accounts of bhakti saints may have been composed and attributed to these saints well after their lifetimes. He does this in part by attending to the meaning of authorship for those memorializing these saints and the interdependence of (auto-)biographical narratives and artistic expressions. Forging a coherent consistency between these two bodies of literature on a given saint is a serious concern for these memorializers as it serves to establish and solidify the authority and authenticity of both sets of texts simultaneously. Instead of focusing on which verses can be most confidently traced to these individuals who purportedly lived in a certain place at a certain time, Hawley suggests that these saints might be viewed almost as genres in themselves, that there are many Sūrs, Mīrās, and Kabīrs who composed poems under these names because those poems are in some way true to the meaning and purpose of these saints.

One of the difficulties faced by scholars like Hawley is that at times it is impossible to trace who composed these later poems and under what circumstances. ${ }^{1}$ When such information is known, which is more often the case with hagiographies than it is with poetry, one can begin to unravel how the image and understanding of a saint has been changed over time in relation to particular historical contexts and how alterations to that saint's legacy may have served particular purposes in those historical moments.

This special issue aims to contribute to these ongoing conversations about the significance of hagiography with regard to Hindu saints, especially the role of hagiography in the memorialization and commemoration of saints that are pivotal in social and political reimaginings of religious traditions. Each paper addresses different constellations of theoretical issues, temporalities, and layers of memorialization related to different saints, societies, and traditions. However, they all address how hagiography and other forms of remembrance are always situated in the social and political contexts of those recalling and invoking the saints, including both those currently memorializing the saints and those who memorialized them in the past whom current memorializers draw upon. This dialectic between current traditions, memorializers of the past, and the saints themselves is profoundly productive in shaping religious traditions, their position in their broader social and political worlds, and our own understanding of the past and the saints that dwelled therein.

In "Vernacularizing Jñāndev," Christian Lee Novetzke analyzes how the famous early Marathi text titled the Jñāneśvari and the hagiographical reconstructions of the saint Jñāndev, especially by the later saint Nāmdev, enact different kinds of

\footnotetext{
${ }^{1}$ It should be noted that at times it is possible to trace to some degree the people who composed these later poems and under what circumstances, and such information can lend itself to fruitful sociohistorical analysis. For example, see Novetzke's Religion and Public Memory (2008) in which he examines the poetry of Viṣnudāsa Nāma, who wrote under his own name as well as that of Nāmdev.
} 
vernacularization beginning in the late thirteenth century. Bringing together scholarship on vernacularization as a shift in medieval literary culture and as a contemporary sociopolitical process, Novetzke redefines vernacularization as a "valorization of everyday life, the appropriation of its idioms, and a reconfiguration of public politics that deeply engages ideas of the quotidian." Within this framework, the vernacular Jñāneśvarī demonstrates Jñāndev's pursuit of sonic equality without necessarily social or political equality. It is only with Nāmdev and later hagiographers' memorializations of Jñāndev that Jñanndev himself is vernacularized and deployed as a revered saint who advocated for social and political equality through a valorization of the quotidian and everyday life. Thus, hagiography simultaneously reconfigures and deploys the authority of the past in order to enact cultural politics in the present, in this case vernacularizing language, a saint, and Marathi public culture in the pursuit of a number of sociopolitical aims.

In "Orientalism and the Invention of Kashmiri Religion(s)," Dean Accardi traces the hagiographical legacy of the fourteenth-century Kashmiri saint Lal Ded, demonstrating a dramatic shift in her depiction from the earliest accounts in sixteenth-century Persian hagiographies to the twentieth-century Lallā-Vākyāni. While her legacy served sociopolitical ends in both periods, the Lallä-Vākyāni - the first major English translation and publication of poetry attributed to Lal Ded, and thus the source from which much of the world came to learn of this saint-presents itself as an objective, transparent, and comprehensive study of Lal Ded and her poetry. However, investigating the personal correspondence between George Abraham Grierson, Lionel D. Barnett, and their Kashmiri research assistant Mukund Ram Shastri reveals not only a more complicated, if not sordid, research process behind the publication but also an Orientalist agenda to recast the previously religiously ambiguous Lal Ded and the cultural heritage of Kashmir as exclusively Hindu, Romantic, feminine, and Sanskritic. Excising and dismissing connections between Lal Ded and various Șūfī figures in her hagiographical legacy contributed toward casting Hindus and Muslims as mutually exclusive communities and Islam as foreign to Kashmir's true heritage, a conception that served both the imperial aims of Orientalism and the politics of the Dogrā princely state of Jammu and Kashmir. Thus, the Lallā-Vākyāni, as a kind of modern hagiography of Lal Ded, was instrumental to the invention of a Kashmiri Śaiva Hinduism that was simultaneously completely devoid of any connection-religious, historical, or social-with Islam and the true religion and culture of Kashmir, naturalizing and exacerbating the communal politics of the region.

In "Agradās and the Rām Rasik Bhakti Community," Patton Burchett analyzes how eighteenth-century hagiographical writings of the Rām rasik community reshaped the legacy of the late sixteenth-century saint Agradās so as to establish him as the founder of the Rām rasik tradition. In contrast to the earliest archival records that depict Agradās as a Rāmānandī ascetic sant, "Agradās's memory was molded in particular ways in the eighteenth century in order to construct a community-binding and tradition-legitimating authority in his rasik sainthood." Due to the increased legal and social opposition toward warrior asceticism in the eighteenth century, the aestheticization of the Rāmānandī tradition was necessary for its survival, and the portrayal of Agradās as a founding rasik followed in suit. In the twentieth century, 
this reshaping of Agradās's legacy took on new political significance when Rām rasik Rāmānandīs used the claim that Agradās was a rasik and founder of their community to sever their long-standing relationship with the Śrivvaiṣnavas for their perceived elitist and casteist practices. Thus, as Burchett succinctly states, "In key respects, then, a saint is a collective memory, and thus is continuously constructed and reconstructed through time in a social process, a process that is always political and in the service of the historically contingent interests of particular groups. As the case of Agradās will illustrate, in many instances, the politics of making a saint are none other than the politics of building and sustaining a religious community."

In "The Other Trinity," Archana Venkatesan examines the role of the Prasanna Venkateśa Perumāl Temple's Madurai Saurashtra Sabha in the canonization of three nineteenth-century musician-saints: Ven̉kațaramaṇa Bhāgavatar, Kavi Veṅkațasūri, and Nāyakī Svāmikaḷ. Referred to as the Saurashtra mummūrti, these three figures are prominently placed and revered throughout the temple precincts as alternatives to the canonical founders of South Indian classical music: Tyāgarāja, Muttusvāmi Dīkṣitar, and Śyāma Śāstri. Of the three Saurashtra mummūrti, only Svāmikal was from Madurai and lived the majority of his life there. Thus, when the Madurai Saurashtra Sabha claimed the Prasanna Veñkateśa Perumāl Kōyil was a denominational temple in order to prevent its being taken over as a public temple by the state of Tamil Nadu, the Sabha, in concert with other Tamil Saurashtra institutions such as the Siddhāsramam, needed to make exclusive claims over Svāmikal and the rights to his legacy on behalf of the Tamil Saurashtra community. As if to mark the significance and success of this claim, the Sabha erected a sannidhi for Nāyakī Svāmikal three years after winning its court case to retain private control over the Prasanna Venkațeśa Perumāl Temple. Venkatesan argues that the memorializations of these three figures, the Saurashtra mummūrti, "ultimately converge around questions of Saurashtra autonomy (as expressed through caste identity), and it is precisely when such questions are most imminent that activities of the Saurashtra Sabha and Siddhāsramam [for example, the push to canonize a Saurashtra mummürti] have become most urgent." These events surrounding the legacies of Svāmikal and the Saurashtra mummūrti demonstrate how political pressure leads to an urgent canonization of saints with a rememorialization that articulates caste, class, gender, and ethnic identities.

In "From Neither/Nor to Both/And," Jonathan Loar addresses a shift in the framing of the late nineteenth-century saint Shirdi Sai Baba from being "neither Hindu nor Muslim" to "both Hindu and Muslim." Tracing this transition as occurring between the writing of two major hagiographies, G. R. Dabholkar's Marathi Śrī Sā̄ Satcarita and B. V. Narasimhaswami's English Life of Sai Baba, Loar argues that Narasimhaswami pursued this change in order to popularize and integrate Sai Baba into an Indian national politics of Hindu-Muslim unity. However, Narasimhaswami's "both/and" image is unequal. By claiming Sai Baba was born a Brāhmaṇa and formally initiated by a Hindu guru, Narasimhaswami identifies Sai Baba as predominantly Hindu, whereas Sai Baba's "Muslim-ness" is minimized and contained. Through his use of the English language, a more popular literary form, and concerted efforts to spread Sai Baba's legacy to the upper strata of Indian society in line with popular national politics of the period, Narasimhaswami's 
refashioning of Sai Baba as mostly Hindu and subordinately Muslim appears to have successfully pervaded the saint's legacy in popular imagination. Through his examination of these shifts in accounts of Sai Baba's life and legacy, Loar argues that the nature of hagiography is such that the silences or lacunae in first-generation hagiographies, whether intentional or not, function as vacuums that beg to be filled by later hagiographies. Since these vacuums are filled in different ways for different ends in response to different contexts, hagiography is revealed as political discourse.

Finally, in "Spiritual Heroes, Miracle Tales, and Rāmsnehī Foundations," Daniel Gold engages in a close literary analysis of the sant Vintiram Rāmsnehī's Śrī Rāmcaraṇj̄ Mahārāj kā Jìvan Caritra, a recent hagiographical "biography" of Rāmcaran, the eighteenth-century Rajasthani saint and founder of the Shahpura Rāmsnehī tradition. Gold argues that Vintiram's text functions in at least two different ways. On the one hand, it is, as one might expect, "the story of a miracleworking saint who inspires often prosperous and increasingly globalized late twentieth-century sectarian devotees through his [Rāmcaraṇ's] teachings and felt spiritual presence." On the other hand, Vintiram's Jivan Caritra is consciously built upon successive layers of Rāmsnehī hagiographical tradition, especially the Brahmlīnsamāahi Jog and Gurulīlā Vilās of Jagannath, a disciple of Rāmcaran from the mercantile Māheśvarī trading caste. By providing glimpses into these earlier hagiographies that depict Rāmcaran as a unique spiritual hero towards whom the merchant community of a realistically portrayed religiopolitical world of eighteenth-century Rajasthan gravitated, Vintiram's Jivan Caritra reveals how a contemporary hagiographer reconstructs an earlier, alternative construction of a saint to meet the needs of a late twentieth-century audience. Whether it involves shifting the emphases of Rāmcaran's teachings to appeal to a broader audience, including previously absent miraculous tales of the saint, or emphasizing the saint's activities at now-popular pilgrimage locations, Vintiram's simultaneous reconstruction and revelation of earlier Rāmsnehī hagiographies serves to increase our understanding of the dynamic changes occurring in these later phases of sant traditions well after the time of the most famous sant figures of the fifteenth and sixteenth centuries.

Hindu saints are made and re-made through memorialization. Demanding the attentive use of historical, anthropological, literary, and other methods of analysis, hagiographies and other forms of memorialization reveal much more than information about particular saints. At the very least, they function as records of particular memorializations and the social processes surrounding them. They therefore provide a valuable resource by which scholars can analyze how and why different saints are considered saints at different historical moments as well as the broader, surrounding contexts in which these processes take place. Through such analysis, scholars may reveal the greater social, political, and religious dynamics faced by different memorializers, and thus the stakes involved in their memorializations. It is our hope that through these papers we have contributed to the growing body of scholarship that aims to forge rigorous approaches to the making of Hindu saints and more nuanced understandings of the politics shaping their legacies. 


\section{References}

Hawley, John Stratton. 1988. "Author and Authority in the Bhakti Poetry of North India." The Journal of Asian Studies 47, 2: 269-90.

Lifshitz, Felice. 1994. "Beyond Positivism and Genre: 'Hagiographical' Texts as Historical Narrative." Viator 25: 95-113.

Novetzke, Christian Lee. 2008. Religion and Public Memory: A Cultural History of Saint Nāmdev in India. New York: Columbia University Press. 